\title{
KARAKTERISTIK TOKOH UTAMA DALAM BAGIAN PERTAMA NASKAH DRAMA AHLUL KAHFI KARYA TAUFĪQ AL-CHAKĪM: ANALISIS PSIKOLOGI SASTRA
}

\author{
Lia Yuniartha \\ liayuniartha@gmail.com \\ Eva Farhah \\ evafarhah@staff.uns.ac.id \\ Program Studi Sastra Arab \\ Fakultas Ilmu Budaya Universitas Sebelas Maret Surakarta
}

\begin{abstract}
Abstrak
Artikel ini bertujuan untuk mengetahui karakteristik tokoh utama dalam bagian pertama naskah drama Ahlul Kahfi karya Taufĩq Al-Chakīm dengan menggunakan pendekatan psikologi kepribadian Carl Gustav Jung. Untuk mencapai tujuan tersebut, metode penelitian ini mengikuti langkah-langkah sebagai berikut: (1) Pembacaan karya yang menjadi objek penelitian, (2) Perumusan masalah, (3) Penentuan data objek, (4) Pengumpulan sumber data, (5) Pengkajian struktur, (6) Analisis data, dan (7) Penarikan kesimpulan. Hasil yang didapat adalah para tokoh utama memiliki karakteristik yang didominasi fungsi dan sikap jiwa yang beragam seperti pikiran, perasaan, ekstravers, introvers, dan perpaduan antara kedua sikap tersebut.
\end{abstract}

Kata Kunci: Drama Ahlul Kahfi, Psikologi Sastra, Psikologi Kepribadian, Carl Gustav Jung.

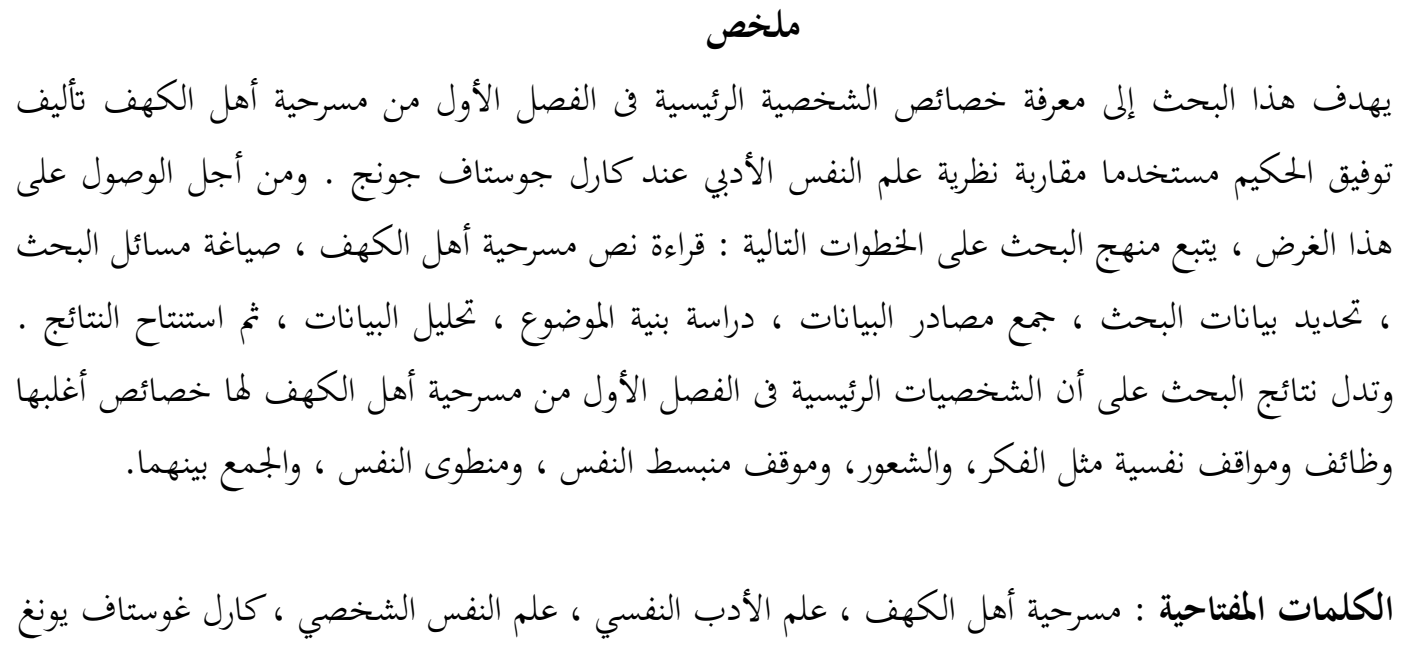




\section{Pendahuluan}

Sastra merupakan suatu kegiatan kreatif yang menghasilkan sebuah karya seni (Wellek dan Warren, 2014: 3). Menurut Farhūd dalam bukunya yang berjudul Al-Baläghah wa An-Naqad (1981: 123), pengertian sastra adalah sebuah ungkapan kebahasaan yang indah mengenai kehidupan yang memiliki beragam genre dan terhimpun dalam dua kategori besar, yaitu puisi dan prosa.

Sastra ini menghasilkan sebuah karya yang disebut dengan karya sastra. Berdasarkan genre-nya, Farhūd (1981: 123) membagi karya sastra menjadi tiga macam, yaitu prosa, puisi, dan drama. Drama yang merupakan salah satunya memiliki pengertian di antaranya (1) Komposisi syair atau prosa yang diharapkan dapat menggambarkan kehidupan dan watak melalui tingkah laku (akting) atau dialog yang dipentaskan; (2) Cerita atau kisah terutama yang melibatkan konflik atau emosi, yang khusus disusun untuk pertunjukan teater; (3) Kejadian yang menyedihkan (Kamus Besar Bahasa Indonesia, 2008: 213).

Genre sastra sendiri dapat ditinjau dengan berbagai pendekatan yang salah satunya dengan menggunakan pendekatan psikologi sastra. Pendekatan ini tidak ditujukan untuk memecahkan masalahmasalah dalam realitas kehidupan seperti yang telah disinggung di atas, namun psikologi sastra memiliki tujuan memahami aspek-aspek kejiwaan yang terkandung dalam sebuah karya sastra, terlebih lagi melalui penggambaran tokoh utama serta penokohannya (Endraswara, 2008: 9-11).

Hubungan antara sastra dan psikologi adalah bahwa di satu sisi karya sastra erat kaitannya dengan kehidupan nyata karena terlahir dari kehidupan sehari-hari berupa pengungkapan masalah hidup serta kejiwaan. Pada sisi yang lain ilmu psikologi dapat membantu mengetahui aspek-aspek kejiwaan dalam karya sastra. Artinya, segala aktivitas dalam diri manusia yang terkait dengan kondisi kejiwaan dapat diketahui melalui ilmu tersebut (Endraswara, 2008: 9).
Secara umum, pengertian pendekatan psikologi sastra merupakan sebuah interdisiplin antara psikologi dan sastra (Endraswara, 2008: 14). Pendekatan ini dilakukan dengan cara mengkaji karakteristik serta kepribadian tokoh pada suatu karya sastra.

Taufīq Al-Chakīm yang merupakan salah satu sastrawan Arab modern yang berpengaruh di Mesir lahir pada tanggal 9 Oktober 1898 di Kota Iskandariyah, Mesir. Dia merupakan perintis lahirnya novel sekaligus drama Arab di Mesir. Dia juga merupakan sastrawan internasional yang dijuluki bapak drama Arab modern. Dia telah menulis lebih dari 50 naskah drama, dan beragam novel dengan berbagai tema. Di antara karya-karya dramanya seperti Ahlul Kahfi (The People of The Cave, 1933), Audat Ar-Ruuh (1933), dan Syahrazad (Scheherazade, 1934).

Karya Taufĩq Al-Chakīm yang berjudul Ahlul Kahfi menjadi salah satu karya terbaiknya yang mampu memberi perubahan signifikan pada sejarah kesusastraan Mesir. Hal ini dikarenakan cerita yang diangkat oleh Al-Chakīm ini merupakan cerita fenomenal yang terdapat di dalam Al-Qur'an serta beberapa kitab dan sumber lain, sehingga masyarakat Mesir dan yang lainnya dapat menerima karya tersebut dengan antusias.

Ahlul Kahfi mengangkat kisah tiga pemuda yang tertidur di dalam sebuah gua yang gelap. Beratus-ratus tahun kemudian ketiganya terbangun karena lelah atas tidur yang mereka pikir hanya selama beberapa hari saja. Mereka rela mengorbankan apa yang mereka cintai seperti keluarga, kekasih, dan bahkan kehidupan yang mereka cintai dan memilih untuk bersembunyi dari pembantaian yang dilakukan Raja Diqyānūs. Hal tersebut terjadi karena mereka memeluk agama yang dibenci oleh raja tersebut.

Keyakinan agama yang dimiliki Misylīnia, Marnūsyī, dan Yimlīkha tetap mereka pertahankan hingga akhir hayat. Naskah ini juga menceritakan kesetiaan Marnūsyī terhadap sahabatnya, Misylīnia, serta persahabatan antara Misylīnia, 
Marnūsȳ̄, dan Yimlīkha meski seringkali ketiganya terlibat dalam konflik yang bersifat kompleks.

Kajian penelitian ini difokuskan pada karakteristik tokoh utama dalam bagian pertama naskah drama Ahlul Kahfi karya Taufīq Al-Chakīm. Penelitian ini menggunakan pendekatan psikologi teori Carl Gustav Jung. Penelitian dengan judul "Karakteristik Tokoh Utama dalam Bagian Pertama Naskah Drama Ahlul Kahfi karya Taufí Al-Chakim: Analisis Psikologi Sastra" ini berdasarkan hasil penelusuran tinjauan pustaka belum pernah dilakukan oleh para peneliti terdahulu.

Penulis memilih untuk mengkaji naskah drama Ahlul Kahfi karya Taufiq Al-Chakīm ini dikarenakan beberapa alasan. Pertama, penulis menemukan sejumlah konflik yang menandai perpaduan karakteristik yang kuat antar tokoh. Para tokoh memiliki karakteristik dan ciri yang beragam sehingga mampu menghidupkan suasana yang ada di dalam naskah drama ini.

Kedua, naskah ini juga memiliki keindahan alur cerita yang menarik untuk dikaji. Alur yang digunakan dalam naskah ini merupakan alur maju yang dipadukan dengan alur mundur saat menceritakan kejadian di masa lalu. Naskah ini memiliki ciri khas alur lintas masa dengan pautan kurang lebih 300 tahun.

Selain itu, Taufìq Al-Chakīm ini juga banyak mengangkat kisah yang fenomenal dan melegenda seperti Ashabul Kahfi dan Syahrazad. Kisah Ashabul Kahfi diangkat Taufĩq Al-Chakīm dalam naskah dramanya yang berjudul Ahlul Kahfi atau Ahl Al-Kahf pada tahun 1933. Kisah ini dapat ditemukan dalam surat kedelapan $(Q S$ Al-Kahfi $)$ di dalam AlQur'an dan sumber-sumber lain seperti buku-buku cerita Ashabul Kahfi yang dapat dengan mudah diakses masyarakat. Dia memberikan sentuhan kebudayaan yang bersifat intelektual dalam naskah drama ini. Inilah yang membuat masyarakat di seluruh dunia selaku penikmat karya sastra tertarik dengan karya asli yang dilahirkan dari Timur Tengah tersebut.
Inilah yang menjadi alasan penulis untuk mengungkapkan karakteristik dan konflik tokoh-tokoh dalam naskah drama tersebut. Dengan berbagai latar belakang permasalahan di atas, penulis tergerak untuk melakukan penelitian dan pengkajian judul tersebut.

Penulis berharap penelitian ini dapat membantu para penikmat karya sastra dalam memahami alur cerita naskah drama Ahlul Kahfi karya Taufĩ AlChakīm, serta dapat menambah pengetahuan mengenai kajian psikologi sastra Carl Gustav Jung. Selain itu penulis juga berharap dengan diungkap dan dijabarkannya karakteristik dan konflik tokoh-tokoh dengan menggunakan teori kepribadian Gustav Jung, penelitian ini dapat menjadi pembelajaran bagi para pembaca dalam memahami serta mendalami karakter pribadi serta orang lain yang berada di sekitarnya.

\section{Kajian Teori}

1. Teori Psikologi

Psikologi sastra merupakan sebuah teori yang difungsikan untuk mengetahui psikologi serta karakteristik para tokoh yang terdapat dalam sebuah karya sastra. Mempelajari psikologi sastra sebenarnya sama halnya dengan mempelajari manusia dari sisi dalam (Endraswara dalam Minderop, 2011: 59). Lebih lanjut Endraswara menegaskan bahwa daya tarik psikologi sastra adalah pada masalah manusia yang melukiskan potret jiwa.

Psikologi sastra ini pada hakikatnya dibangun dengan asumsi-asumsi genesis, hal ini terkait erat dengan asal usul sebuah karya sastra (Minderop, 2010: 61). Terdapat beberapa pandangan yang menyatakan perkembangan psikologi sastra agak lamban dikarenakan beberapa sebab. Penyebab adanya perbedaan tersebut antara lain: pertama, psikologi sastra seolah-olah hanya berkaitan dengan manusia sebagai individu, kurang memberikan peranan terhadap subjek transindividual, sehingga analisis dianggap sempit. Kedua, dikaitkan dengan tradisi intelektual, teori-teori sangat terbatas sehingga para sarjana sastra kurang memiliki pemahaman terhadap 
bidang psikologi sastra. Alasan di atas membuat psikologi sastra kurang diminati untuk diteliti (Ratna dalam Minderop, 2010: 65).

\section{Teori Kepribadian Jung}

Secara garis besar teori psikologi Jung mengungkapkan bahwa jiwa manusia terbagi menjadi dua bagian, yaitu alam sadar (kesadaran) dan alam tak sadar (ketidaksadaran). Kedua alam tersebut tidak hanya saling mengisi, namun juga selalu berhubungan secara kompensatoris (Suryabrata, 2007: 157).

a. Struktur Kesadaran

Struktur kesadaran yang dikemukakan Jung ini memiliki dua komponen utama di antaranya fungsi jiwa dan sikap jiwa. Selain itu terdapat pula komponen tipologi Jung dan persona yang terkait dengan dua komponen tersebut dengan penjelasan sebagai berikut.

1) Fungsi Jiwa

Seperti halnya pengertian dasar kata "fungsi", fungsi jiwa ini menjelaskan bahwa suatu jiwa memiliki fungsi yang berbeda-beda. Pada dasarnya setiap manusia memiliki fungsi-fungsi tersebut, namun hanya satu fungsi saja yang lebih dominan dari lainnya, dan fungsi dominan itulah yang menyiratkan sifat manusia tersebut (Suryabrata, 2007: 158). Fungsi-fungsi tersebut adalah sebagai berikut.

a) Pikiran

Pikiran adalah fungsi jiwa yang bersifat rasional. Fungsi ini menilai sesuatu berdasarkan benar dan salah (Jung dalam Suryabrata, 2007: 158).

b) Perasaan

Fungsi perasaan ini bersifat rasional dengan penilaian berdasarkan senang dan tidak senang terhadap sesuatu (Jung dalam Suryabrata, 2007: 158).

c) Pendriaan

Fungsi ini bersifat irrasional dan tidak memberikan penilaian terhadap sesuatu, namun hanya melakukan pengamatan berdasarkan aspek sadar dan indriah saja (Jung dalam Suryabrata, 2007: 159).

d) Intuisi

Fungsi intuisi ini merupakan fungsi terakhir dalam konsep kesadaran menurut Jung. Fungsi ini juga bersifat irrasional dan tidak memberikan penilaian atas sesuatu. Intuisi ini hanya mendapat pengamatan secara tak sadar dan bersifat naluriah semata (Jung dalam Suryabrata, 2007: 159).

2) Sikap Jiwa

Sikap jiwa adalah arah daripada energi psikis umum yang menjelma dalam bentuk orientasi manusia terhadap dunianya. Bentuk orientasi manusia ini dapat mengarah ke luar (dunia sekitarnya), atau mengarah ke dalam (diri manusia itu sendiri). Berdasarkan hal tersebut, sikap jiwa manusia dapat dibedakan menjadi dua; ekstravers dan introvers, dengan penjelasan sebagai berikut.

\section{a) Ekstravers}

Seseorang dapat dikatakan memiliki sikap ekstravers jika keseluruhan sikapnya didominasi oleh dunia di luar dirinya. Sikap ini lebih mengutamakan kepentingan lingkungan sosial dan sekitarnya daripada kepentingan untuk dirinya sendiri.

Seseorang dengan sikap ekstravers yang lebih dominan ini cenderung terbuka dalam berhubungan dengan orang-orang di sekitarnya, mudah bergaul, dan memiliki pikiran yang terbuka untuk lingkungan sosialnya. Namun sikap ini tidak sepenuhnya baik bagi jiwa. Sikap yang terpengaruh oleh dunia obyektif ini akan membuat seseorang merasa kehilangan dirinya atau asing dengan dirinya sendiri jika sikap ini terlampau kuat (Jung dalam Suryabrata, 2007: 162).

b) Introvers

Sikap yang kedua adalah sikap introvers yang memiliki ciri yang bertolak belakang dengan 
sikap ekstravers. Sikap ini dipengaruhi oleh dunia subyektif, sehingga pikiran dan perasaannya cenderung ditujukan untuk dirinya sendiri tanpa mempedulikan hubungannya dengan lingkungan sekitarnya.

Seseorang dengan kepribadian seperti ini memiliki sifat yang tertutup, sulit bergaul, dan kurang berharmonisasi dengan lingkungan sosialnya, namun untuk koordinasi dengan dirinya sendiri ia cukup baik. Jika sikap ini dibiarkan terus menerus, maka yang akan terjadi adalah adanya jarak yang cukup jauh dengan lingkungan obyektifnya (Jung dalam Suryabrata, 2007: 162).

c) Tipologi Jung

Melalui kedua komponen utama di atas, Jung (dalam Suryabrata, 2007: 163) membuat penggabungan komponen fungsi dan struktur jiwa. Penggabungan tersebut dibuat dengan menyilangkan dua komponen antara fungsi dan sikap jiwa seperti contoh penggabungan antara fungsi pemikir dalam struktur kesadarannya bertolak belakang dengan fungsi perasa dalam struktur ketidaksadarannya.

\section{Analisis Karakteristik Tokoh Utama dalam Naskah Drama Ahlul Kahfi Karya Taufĩq Al-Chakīm}

Naskah drama ini mengisahkan tiga pemuda yang tertidur di dalam sebuah gua yang gelap. Beratus-ratus tahun kemudian ketiganya terbangun karena lelah atas tidur yang mereka pikir hanya selama beberapa hari saja. Mereka rela mengorbankan apa yang mereka cintai seperti keluarga, kekasih, dan bahkan kehidupan yang mereka cintai dan memilih untuk bersembunyi dari pembantaian yang dilakukan Raja Diqyānūs. Hal tersebut terjadi karena mereka memeluk agama yang dibenci oleh raja tersebut.
Babak pertama dalam naskah ini menggunakan latar tempat sebuah gua yang gelap dan tidak dapat dijangkau oleh masyarakat saat itu. Tokoh utama yang terdapat di dalam babak pertama ini ada empat, yaitu tokoh Misylīnia, tokoh Marnūsyī, tokoh Yimlīkha, dan tokoh Raja Diqyānūs dengan penjelasan karakteristik berdasarkan struktur kesadaran sebagai berikut.

a. Tokoh Misylīnia

Tokoh Misylīnia merupakan salah satu menteri Raja Diqyānūs yang memeluk agama Masehi. Ia memiliki seorang kekasih bernama Putri Priska yang juga merupakan anak perempuan dari raja tersebut. Berdasarkan analisis menggunakan teori kepribadian Jung, Misylīnia memiliki kepribadian yang dominan terhadap fungsi perasaan. Hal ini terlihat pada rasa cinta yang ditujukan untuk kekasihnya, Putri Priska. Cinta merupakan salah satu unsur rasa yang dapat melambangkan kesenangan terhadap sesuatu atau seseorang.

Pada naskah drama ini, Misylīnia menunjukkan rasa cintanya secara beruntun. Beberapa kali dia mencoba untuk keluar dari gua yang melindunginya itu hanya untuk mengobati rasa rindunya kepada kekasihnya, seperti yang terdapat pada kutipan dialog berikut.

$$
\begin{aligned}
& \text { مشاينيا : وأنت؟ ألا تريد أن تستبقى } \\
& \text { حياتك من أجل ... - ل } \\
& \text { مرنوش : نعم يا مرنوش, لكن ها أنت ذا ذا } \\
& \text { ترانى لا أقوى على البعد يوما } \\
& \text { واحد }
\end{aligned}
$$

Artinya:

Marnūsyī: "Kamu sendiri?

Bukannya kamu ingin bertahan hidup untuk..."

Misylīnia: "Betul Marnūsyī, tapi seperti yang kamu tahu, aku tidak akan bisa jauh darinya sehari saja."

Kalimat "Aku tidak akan bisa jauh darinya sehari saja" pada dialog di 
atas menunjukkan rasa cinta yang dalam. Dialog di atas bermakna dia yang tengah bersembunyi di dalam gua bersama kedua kawannya tidak mampu membendung cintanya terhadap Putri Priska. Rindu telah membuatnya ingin segera keluar dari tempat gelap tersebut. Dalam dialog lain juga ditunjukkan unsur cinta Misylīnia di antaranya sebagai berikut.

$$
\begin{aligned}
& \text { مرنوش : اه.! ستذهب طبعا بعد ذلك } \\
& \text { إلى خيث تراها أيها الخبيث! } \\
& \text { مشاينيا : وأى ضرر في هذا ؟ إنا } \\
& \text { تنتظرن هي أيضا, تنتظر منى } \\
& \text { خبرا. أتذكر يوم وقفت خلف } \\
& \text { الباب تحملنا على الهرب؟ أتدرى } \\
& \text { ما قالت لى وهى تودعنى وأنت. }
\end{aligned}
$$

Artinya:

Marnūsyī: "Oh... setelah semua ini? Kamu hanya mencari alasan untuk menemuinya kan?"'

Misylīnia: "Apa salahnya? Kamu tahu dengan baik kalau saat ini Priska sedang menungguku. Menunggu kabar dariku. Ingat kan mengapa dia rela berdiri menunggu kita di belakang pintu? Supaya kita berdua selamat, Marnūsyī."

Dialog-dialog di atas menunjukkan bahwa fungsi perasaan yang diwakili cinta dan rindu lebih mendominasi daripada fungsi-fungsi yang lain. Kedua rasa itu juga yang kemudian melumpuhkan fungsi pikiran beserta fungsi-fungsi yang lain di dalam jiwa tokoh Misylīnia. Hal tersebut berakibat pada pembutaan akal dan pikiran seperti yang terdapat pada kutipan dialog Marnūsyī di bawah ini.

$$
\text { مرنوش : : لكنك هذه المرة قد ذهب }
$$

$$
\begin{aligned}
& \text { دفعت الرسالة إلى وصيفة غيرى } \\
& \text { تضمر لكما الشرّ... ألا تذكر } \\
& \text { أنى نبهتك يوما أليها وقد لحظت التسر } \\
& \text { منها أشياء. أولم بتح رسولا سوى لينات وقد }
\end{aligned}
$$

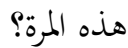

Artinya:

Marnūsyī:"Tapi tetap saja. Otak cerdasmu itu hilang begitu saja. Kaтu justru menulis surat tanpa menyadari bahaya yang mengancam. Kenapa surat itu kamu kirim melalui dayang Ghayara. Aku pernah menemukan hal-hal tidak wajar dengan apa yang dia lakukan. Apakah tidak ada orang lain yang bisa menyampaikan suratmu kepada Priska?',

Fungsi pikiran merupakan fungsi jiwa yang bersifat rasional. Fungsi ini menilai sesuatu berdasarkan benar dan salah (Jung dalam Suryabrata, 2007: 158). Pada kutipan di atas dijelaskan bahwa tokoh Marnūsyī mengucapkan kalimat "Otak cerdasmu hilang begitu saja". Kalimat itu bermakna kegusaran Marnūsȳi pada perubahan yang terjadi pada sahabatnya, Misylīnia, yang rela melakukan apa saja hanya untuk memuaskan rasa cinta dan rindunya. Dia tidak menyadari bahwa itu akan berakibat buruk pada keselamatan Misylīnia dan juga kedua tokoh yang lain.

Selain itu, dominansi pada fungsi perasaan juga menyebabkan tokoh Misylīnia melakukan kesalahan yang tidak dipertimbangkan sebelumnya. Kesalahan tersebut adalah menitipkan surat cinta untuk kekasihnya kepada seorang dayang yang ternyata mengkhianati dirinya. Hal yang terjadi kemudian adalah dia dan Marnūsyī menjadi sasaran pembantaian Raja Diqyānūs karena kedua tokoh itu menganut agama yang tidak disukai raja 
tersebut. berikut adalah kutipan dialog Marnūsȳ̄ yang mengungkapkan kecerobohan tokoh Misylīnia.

$$
\text { مرنوش : بل أحمداله على أن رسالتك المشئومة لم يكن بها غير اسمينا }
$$

Artinya:

Marnūsȳi: "Aku bersyukur pada Allah. Surat sialmu itu untungnya hanya menyebut kita berdua saja."

Terdapat pula dialog lain yang menunjukkan karakter keras kepala tokoh Misylīnia meski Marnūsyī telah mencoba memperingatkannya berulangkali terkait hubungan cintanya tersebut.

$$
\begin{aligned}
& \text { مرنوش : : طالمال حذرتك الكتابة إلى } \\
& \text { مشاينيا : بريسا }
\end{aligned}
$$

Artinya:

Marnūsȳ: "Aku sudah mengingatkan untuk tidak menulis surat pada Priska."

Misylīnia: "Shhh!!!"

Kutipan dialog di atas menunjukkan tokoh Misylīnia yang tidak senang terhadap apa yang dikatakan tokoh Marnūsyī. Meski begitu, pada akhirnya tokoh Misylīnia mengakui kesalahannya. Hal ini membuktikan bahwa meskipun fungsi perasaan dalam jiwa Misylīnia lebih mendominasi, namun fungsi pikiran dan yang lain tetap ada. Berikut adalah dialog yang menunjukkan fungsi pikiran Misylīnia tetap bekerja.

$$
\begin{aligned}
& \text { مشاينيا : سأذهب ألى الملك توا وأقول } \\
& \text { له: ((إن جنيت على مرنوش } \\
& \text { ظلما, وإن اسمه في الرسالة لا لا }
\end{aligned}
$$

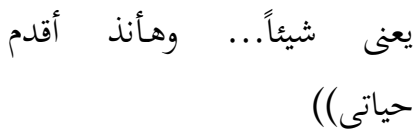

Artinya:

Misylīnia: "Aku akan menghadap Baginda Raja, dan menyampaikan bahwa, "Saya telah melakukan kesalahan, Baginda. Nama Marnūsȳ̄ dalam surat saya tidak berarti apa-apa. Dia tidak bersalah. Mohon bebaskan dia. Saya akan mempersembahkan hidup saya seutuhnya kepada anda, Yang Mulia...'

Kemudian terdapat pula dialog yang menunjukkan Misylīnia tetap mampu membedakan mana yang benar atau salah sebagai berikut.

$$
\begin{aligned}
& \text { مشاينيا : يمليخا! كلمة ((مولاى)) تؤذى } \\
& \text { سمعى, أنا هنا إخوة ومسيحيون } \\
& \text { فلا موالى ولا عبيد. }
\end{aligned}
$$

Pada dialog di atas, Misylīnia menolak julukan "Maulay" yang diberikan Yimlīkha padanya. Hal ini menunjukkan bahwa dia tetap mampu berpikir secara sadar untuk menentukan mana yang baik dan mana yang buruk.

Karakter tokoh Misylīnia memiliki sikap ekstravers, yaitu sikap yang cenderung terbuka dalam berhubungan dengan orang-orang di sekitarnya, mudah bergaul, dan memiliki pikiran yang terbuka untuk lingkungan sosialnya. Namun sikap ini tidak sepenuhnya baik bagi jiwa. Sikap yang terpengaruh oleh dunia obyektif ini akan 
membuat seseorang merasa kehilangan dirinya atau asing dengan dirinya sendiri jika sikap ini terlampau kuat (Jung dalam Suryabrata, 2007: 162).

Sikap yang ditunjukkan Misylīnia yaitu perhatian serta pemikirannya yang ditujukan pada sahabat, dan kekasihnya. Hal tersebut mengungkapkan bahwa tokoh tersebut tidak hanya memikirkan serta mementingkan dirinya sendiri, namun juga mementingkan orang-orang di sekitarnya. Hal ini terlihat pada dialog Misylīnia yang tidak tertutup pada orang lain, serta tetap berusaha memikirkan orang lain.

\section{b. Tokoh Marnūsyī}

Tokoh ini merupakan sahabat tokoh Misylīnia yang juga salah satu menteri kepercayaan Raja Diqyānūs selain Misylīnia. Meskipun pada babak pertama tokoh ini cenderung menunjukkan kemarahan kepada Misylīnia, namun dia tetap sahabat Misylīnia yang akan selalu mengorbankan apapun demi kebahagiaan sahabatnya itu. Karakter yang terdapat di dalam jiwa tokoh ini lebih dominan terhadap fungsi pikiran daripada fungsifungsi lainnya. Hal ini terjadi karena tokoh ini mengutamakan apa yang menurutnya benar, dan menyalahkan apa yang menurutnya salah. Seperti pada kutipan dialog berikut.

$$
\text { مشاينيا : أريد الخروج من هذا المكان }
$$

Artinya:

Misylinia: "Huh. Aku akan keluar saja dari sini."

Marnūsyī: "Masih juga? Oh... kamu memang musibah untukku."

Pada kutipan di atas terdapat kalimat "Oh, kamu memang musibah untukku" yang ditujukan tokoh Marnūsȳ kepada Misylīnia. Kalimat tersebut diucapkan karena tokoh Marnūsȳi melihat gelagat ketidakbenaran dalam diri Misylīnia. Dia kecewa atas kesalahan yang dilakukan Misylīnia hingga berdampak pula padanya. Dalam dialog tersebut dia mencoba menegur serta membuat Misylīnia sadar akan akibat dari kecerobohannya itu.

Kecerobohan itu berawal dari surat yang dikirim Misylīnia untuk kekasihnya. Kemudian surat tersebut dititipkan pada dayang yang ternyata mengkhianatinya. Hingga kemudian Misylīnia dan Marnūsyī menjadi sasaran pembantaian Raja Diqyānūs. Tokoh Marnūsȳi merasa berhak untuk menegur sahabatnya itu karena dia telah berulangkali memperingatkan tokoh Misylīnia atas hubungan cinta dengan Putri Priska. Namun Misylīnia tidak mendengarkan nasehat kawannya tersebut.

Fungsi pikiran yang ditunjukkan tokoh Marnūsyī juga terdapat dalam dialog di bawah ini.

$$
\begin{aligned}
& \text { مشاينيا : قلت لك لا أستطيع المكث } \\
& \text { هنا يوما آخر. } \\
& \text { مرنوش : أيها النزق! أما كفاك أنك } \\
& \text { أوقتعتنا فيما نحن فيه؟ }
\end{aligned}
$$

Artinya:

Misylinnia: "Sudah kubilang. Aku tidak bisa bertahan di sini lebih dari sehari, Marnūsyli.."

Marnūsyī: "Dasar sembrono!!!! Masih belum cukupkah apa yang kamu lakukan sampai kita semua terjebak di sini???"

Dalam dialog tersebut, Marnūsȳ̄ mencoba menyadarkan sahabatnya untuk tidak gegabah dan berpikir dahulu sebelum melakukan sebuah tindakan. Pengetahuannya mengenai nilai kebenaran dan nilai kesalahan membuat Marnūsȳi tetap bertahan untuk mencoba menyadarkan pikiran sahabatnya, Misylīnia.

Selain itu fungsi pikiran yang mendominasi kepribadian Marnūsȳi ini juga terlihat pada karakter tokoh Marnūsyī yang memiliki pemikiran yang cemerlang. Hal ini terlihat pada 
bagaimana dia begitu pandai dalam menyiasati sesuatu seperti saat ia menyiasati kepergian tokoh Misylīnia dan Putri Priska untuk beribadah. Berikut merupakan kutipan dialognya.

$$
\begin{aligned}
& \text { مشاينيا : بفضل رأيك و ومعونتك. } \\
& \text { مرنوش! حقا لست أنسى حرج } \\
& \text { موقفك يومئذ وقد لبثت بعد } \\
& \text { ذهابنا ترقب عودتنا وتقول } \\
& \text { لدقيانوس إذا يسأل عن ابنته إذها } \\
& \text { مع وصائفها في الحمام, ونقول } \\
& \text { لوصائفها القلقات هى هن عند } \\
& \text { أبيها. أجل! }
\end{aligned}
$$

Artinya:

Misylinia: "Semua tidak akan terjadi jika kau tidak membantuku, Marnūsȳi. Sungguh. Aku takkan lupa bagaimana aku membuatmu berada dalam posisi yang sulit. Kaтu selalu menjaga kami. Menunggu kepulangan kami dari gereja. Jika Baginda Raja Diqyānūs menanyakan tuan putri, kamu akan menjawab bahwa Amirah Priska di kolam pemandian bersama para dayang. Kepada para dayang Amirah Priska kami bilang kalau tuan putri tengah bersama sang ayah. Sungguh Marnūsyī."

Pada dialog di atas, tokoh Misylīnia menjelaskan bahwa sahabatnya, Marnūsyī, merupakan sosok yang selalu ada saat dia membutuhkan. Bahkan terdapat pula kalimat yang berbunyi, "Jika Baginda Raja Diqyānūs menanyakan tuan putri, kamu akan menjawab bahwa Amirah Priska di kolam pemandian bersama para dayang. Kepada para dayang Amirah Priska kami bilang kalau tuan putri tengah bersama sang ayah." Kalimat tersebut menyiratkan siasat cerdik yang digunakan tokoh Marnūsȳ̄ hanya untuk melindungi sahabatnya yang tengah beribadah.

Di samping itu, tokoh Marnūsyī tetap berusaha menyeimbangkan fungsifungsi yang ada di dalam jiwanya. Salah satu fungsi, perasaan, juga terdapat dalam sosok yang terdominasi fungsi pikiran ini. Berikut dialognya.

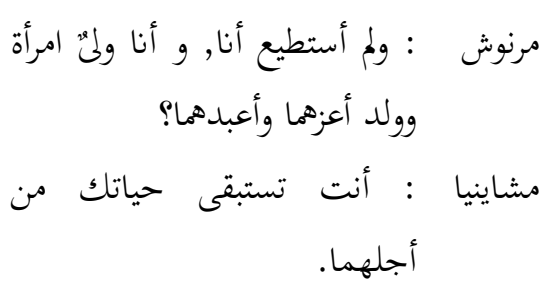

Artinya:

Marnūsyī: "Kenapa? Kenapa aku bisa dan kamu tidak? Padahal aku wali bagi istri dan anakku. Mereka sangat aku sayang dan hormati."

Misylīnia: "Karena kamu ingin selamat untuk mereka berdua."

Fungsi perasaan ini bersifat rasional dengan penilaian berdasarkan senang dan tidak senang terhadap sesuatu (Jung dalam Suryabrata, 2007: 158). Dialog di atas menunjukkan adanya cinta yang diberikan Marnūsȳ̄ kepada keluarganya. Cinta merupakan unsur atau lambang dari fungsi perasaan. Tokoh Marnūsȳi begitu mencintai istri dan anaknya karena memang hanya dua orang itulah yang mampu membuatnya senag dan bahagia. Fungsi ini juga terlihat pada dialog Marnūsȳ̄ yang lain sebagai berikut.

$$
\begin{aligned}
& \text { مرنوش : : نعم... ولكن أية نجاة هذه التى } \\
& \text { تفصل بينى وبين امرأتنوولدى؟ } \\
& \text { آه! كلما أذكر ابنى ينهض هذا } \\
& \text { الصباح ولا أقبله... } \\
& \text { يمليخا :م تحب أهلك! }
\end{aligned}
$$


مرنوش : إنى إنما أحيا بكما وولما... Artinya:

Marnūsȳi: "Betul. Tapi selamat yang seperti apa, Yimlīkha? Aku selamat tapi harus dipisahkan dari istri dan putraku? Ohhh... Bagaimana dengan putraku yang bangun pada pagi ini? Dia tidak mendapatkan ciuman dariku..."

Yimlīkha: "Anda sangat mencintai keluarga anda, Maulay..."

Marnūsyī: "Hanya karena mereka aku hidup. Aku hanya ingin bersama keduanya saja..."

Pada dialog tersebut tokoh Marnūsȳ̄ mengungkapkan secara langsung bahwa dia sangat mencintai istri dan anaknya. Namun cinta pada kedua orang tersebut tak lantas membuat dirinya didominasi oleh cinta dan fungsi perasaan. Karakternya tetap didominasi oleh pikiran yang selalu merujuk pada kebenaran.

Terkait dengan sikap jiwa yang dimiliki, tokoh ini mengunakan prinsip tipologi Jung yang merupakan perpaduan antara sikap ekstravers dan sikap introvers. Hal ini terlihat pada sikap tokoh Marnūsȳ̄ yang mementingkan kedua unsur dalam hidupnya, yaitu dirinya dan orang-orang di lingkungannya.

\section{c. Tokoh Yimlīkha}

Tokoh ini merupakan seorang penggembala kambing yang kemudian membantu tokoh Misylīnia dan tokoh Marnūsyī bersembunyi dari kejaran para pasukan pembantaian Raja Diqyānūs. Dia memiliki seekor anjing yang selalu bersamanya dan bernama Qithmīr. Dia juga merupakan penganut agama Masehi yang taat. Karakteristik yang dimiliki tokoh tersebut berbeda dengan tokohtokoh lainnya. Jika tokoh Misylīnia dan tokoh Marnūsyī menambatkan cintanya pada seseorang atau keluarga, dia tidak demikian. Dia menambatkan cinta seluruhnya hanya untuk Tuhannya. Hal ini terlihat pada beberapa dialog yang selalu mengedepankan kata Tuhan.

$$
\begin{aligned}
& \text { مرنوش : إنى إنما أحيا بمما ووما ... } \\
& \text { يمليخ ا: صبرا! إن رحمة الله قريب. } \\
& \text { Artinya: } \\
& \text { Marnūsyī: "Hanya karena } \\
& \text { mereka aku hidup. Aku } \\
& \text { hanya ingin bersama } \\
& \text { keduanya saja..." } \\
& \text { Yimlīkha: "Sabarlah, Tuan. } \\
& \text { Sesungguhnya Rahmat } \\
& \text { Allah sangatlah dekat." }
\end{aligned}
$$

Pada dialog di atas, dia menunjukkan kata-kata yang realigius. Ini sebagai bukti bahwa kecintaan dan keimanan kepada Tuhannya lebih besar dari apapun. Kalimat "Sesungguhnya Rahmat Allah sangatlah dekat" tersebut menunjukkan keimanan yang kuat.

Kepribadian yang dimiliki tokoh ini didominasi oleh fungsi perasaan. Hal ini terlihat pada dialog tokoh Yimlīkha yang memiliki tingkat keimanan yang tinggi. Keimanan itu sendiri merupakan wujud dari rasa cinta terhadap Tuhan. Keimanan juga menjadi simbol dari adanya fungsi perasaan yang ada di dalam jiwa tokoh tersebut. dengan tingkat keimanan yang kuat menunjukkan fungsi perasaan lebih dominan dari fungsi-fungsi lainnya.

Karakter taat beragama ini kemudian membentuk karakter berpikiran positif dan sabar. Tokoh yang sellau berpikiran positif ini terlihat pada dialog di bawah ini.

$$
\begin{aligned}
& \text { مرنوش : : لو لم تنسل الأميرة بريسكا إلى } \\
& \text { باب القصر تنتظر أوبتنا من لنس الميره بريسا } \\
& \text { صلاة الفصح لتدعونا إلى } \\
& \text { الفرار... - (n) } \\
& \text { يمليخا : هو المسيح شاء لكما النجة }
\end{aligned}
$$

Artinya:

Marnūsyī: "Andai Amirah Priska tidak berlari ke pintu istana, menunggu 
kepulangan kami dari

ibadah Paskah dan

meminta kami melarikan diri, entahlah..."

Yimlīkha: "Al-Masih masih menginginkan kalian berdua selamat, Maulay."

Kalimat "Al-Masih masih menginginkan kalian berdua selamat, Maulay" pada dialog tersebut mengemukakan bahwa tokoh ini tetap berusaha berpikiran positif terhadap Tuhan setelah apa yang dialaminya. Ini menunjukkan bahwa kecintaan tokoh tersebut pada Tuhannya mampu membuatnya meredam gejolak emosi yang dialami kedua kawannya.

Selain itu tokoh ini juga berkarakteristik sabar. Dia tetap tenang meski berada di antara kedua kawannya yang saling tersulut emosi. Hal ini ia tunjukkan pada dialog berikut.

$$
\text { مشاينيا : يا ألمى! ماذا أستطيع لك إذن؟ }
$$

Artinya:

Misylinia: "Ya Ilahi... Lalu apa yang harus aku lakukan untukmu?"

Yimlīkha: "Serahkan semuanya pada Al-Masih."

Pada dialog tersebut terlihat bahwa tokoh Yimlīkha tetap berusaha tenang saat menghadapi keluhan tokoh Misylīnia. Dia berpendapat bahwa Tuhan (Al-Masih) adalah satu-satunya solusi atas setiap permasalahan yang tidak mampu dijawab manusia. Dia juga merupakan sosok yang selalu mendahulukan orang lain ketika berbicara dan dia akan mendengar dengan sepenuh hati. Hal ini menunjukkan bahwa fungsi perasaan tidak hanya dominan di dalam jiwa tokoh itu, namun juga terdapat fungsi-fungsi lain yang turut berperan di antaranya fungsi pendriaan.

Fungsi pendriaan pada tokoh ini terdapat di dalam narasi naskah drama yang mengatakan setelah lama terdiam, tokoh Yimlīkha akhirnya angkat bicara.
Hal ini menunjukkan bahwa ia mendengar serta mengamati apa yang terjadi di antara kedua kawannya. Setelah dia merasa cukup memahaminya, dia kemudian berusaha menetralkan suasana dengan kembali mengingatkan kedua kawannya tentang Tuhan dan ajarannya. Sikapnya dalam menetralkan suasana ini merupakan reaksi atas fungsi pikiran di dalam jiwanya.

Dapat disimpulkan bahwa awalnya sikap dia untuk mendengar dan mengamati merupakan simbol dari fungsi pendriaan. Kemudian terdapat pula sikapnya angkat bicara setelah terdiam cukup lama merupakan simbol dari fungsi pikiran yang berusaha menetralkan suasana dengan menunjukkan apa yang benar dan apa yang salah.

Selain itu terdapat sikap jiwa yang ia curahkan pada sekitarnya. Sikap ini disebut sikap ekstravers, yaitu sikap yang lebih mengutamakan kepentingan lingkungan sosial dan sekitarnya daripada kepentingan untuk dirinya sendiri. Hal ini dia tunjukkan pada setiap dialog tokoh tersebut yang tidak pernah mengutamakan dirinya sendiri, namun memikirkan orang lain di sekitarnya juga (Jung dalam Suryabrata, 2007: 162).

\section{d. Tokoh Raja Diqyānūs}

Selain ketiga tokoh di atas, juga terdapat tokoh Raja Diqyānūs yang memiliki karakteristik kejam, jahat, dan anti agama Masehi. Karakter tokoh ini ditunjukkan pada dialog tokoh lain. Karakter tokoh ini didominasi oleh fungsi perasaan, yaitu fungsi yang bersifat rasional dengan penilaian berdasarkan senang dan tidak senang terhadap sesuatu (Jung dalam Suryabrata, 2007: 158).

Fungsi ini disimbolkan dengan rasa benci dan amarah atas ketidaksenangan tokoh Raja Diqyānūs terhadap agama Masehi yang diyakini rakyat dan kedua menterinya. Kemudian dia membantai setiap orang yang memeluk agama tersebut. dalam penjelasan tersebut, terlihat bahwa fungsi perasaan tidak senang dalam jiwa tokoh tersebut menyebabkan hilangnya akal dan pikiran sehingga dia tidak mampu membedakan 
mana yang benar dan mana yang salah. Berikut merupakan dialog yang menunjukan kebiadaban tokoh tersebut.

$$
\begin{aligned}
& \text { مرنوش : : قل هو سوء المصادفة أن نظهر }
\end{aligned}
$$

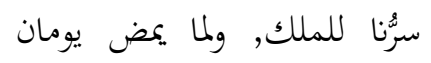

$$
\begin{aligned}
& \text { على أمره بذبح المسيحين. }
\end{aligned}
$$

Dialog di atas menunjukkan kekejaman yang dilakukan tokoh Raja Diqyānūs terhadap pengikut agama Masehi yang juga merupakan rakyatnya. Hal ini terjadi karena dia tidak mampu membedakan mana yang benar dan mana yang salah. Selain fungsi jiwa, karakter tokoh ini juga menunjukkan bahwa dia merupakan sosok dengan sikap jiwa introvers. Sikap ini cenderung ditujukan untuk dirinya sendiri tanpa mempedulikan hubungannya dengan lingkungan sekitarnya (Jung dalam Suryabrata, 2007: 162).

\section{Kesimpulan}

Berdasarkan pengkajian objek yang telah dilakukan peneliti, dapat dikemukakan beberapa kesimpulan di antaranya sebagai berikut.

1. Tokoh Misylīnia

Tokoh ini memiliki karakter fungsi jiwa yang didominasi fungsi perasaan yang disimbolkan dengan cinta dan rindu. Kepribadiannya juga selalu open minded terhadap orang lain di sekitarnya sehingga dapat dikategorikan ke dalam sikap ekstravers.

\section{Tokoh Marnūsȳ̄}

Karakter yang terdapat di dalam jiwa tokoh tersebut cenderung dominan pada fungsi pikiran, yaitu fungsi yang menilai sesuatu berdasarkan benar atau salah (Jung dalam Suryabrata, 2007: 158).
Sedangkan sikap yang ditunjukkan merupakan bentuk tipologi Jung, yaitu perpaduan antara kedua sikap tersebut.

\section{Tokoh Yimlīkha}

Tokoh ini memiliki kecenderungan perasaan pada karakternya. Selain itu dia juga memiliki sikap ekstravers, yaitu sikap jiwa yang cenderung memikirkan orang lain tanpa mengeegokan dirinya sendiri.

4. Tokoh Raja Diqyānūs

Berbeda dengan tokoh yang lain, Raja Diqyānūs ini memiliki karakteristik yang cenderung pada fungsi perasaan. Hal ini terlihat pada ketidaksenangannya terhadap suatu agama Masehi. Kemudian dia mulai kehilangan akal dan membantai para pengikut agama tersebut. fungsi perasaan yang muncul adalah perasaan benci dan amarah. Sedangkan sikap jiwa yang ditunjukkan tokoh tersebut adalah sikap introvers, yaitu sikap yang cenderung ditujukan untuk dirinya sendiri tanpa mempedulikan hubungannya dengan lingkungan sekitarnya (Jung dalam Suryabrata, 2007: 162).

\section{Daftar Pustaka}

Al-Chakīm, Taufīq. 1933. Ahlul Kahfi. Mesir: Dār Mishr Lith-Thibā’ah.

Endraswara, Suwardi. 2008. Metode Penelitian Psikologi Sastra. Yogyakarta: Media Pressindo.

Minderop, Albertine. 2013. Psikologi Sastra: Karya Sastra, Metode, Teori, dan Contoh Kasus. Jakarta: Yayasan Pustaka Obor Indonesia.

Suryabrata, Sumadi. 2007. Psikologi Kepribadian. Jakarta: PT Raja Grafindo Persada. 
Tim Penyusun Kamus Pusat Pembinaan dan Pengembangan Bahasa. 1988. Kamus Besar Bahasa Indonesia. Jakarta: Departemen Pendidikan dan Kebudayaan Republik Indonesia.

Waluyo, Herman J. 2002. Drama: Teori dan Pengajarannya. Yogyakarta: PT. Hanindita Graha Widya.

Wellek, Rene dan Austin Warren. 1990. Teori Kesusastraan. Jakarta: Gramedia.

Sumber Internet

https://en.m.wikipedia.org/wiki/Tawfiq_al - Hakim diakses pada tanggal 23 September 2017 pukul 17.10 WIB.

https://encyclopedia.irank.org/articles/pag es/5699/Hakim-Tawfiq-al--18981987.html diakses pada tanggal
30 Oktober 2017 pukul 15:19 WIB. 